\title{
Effects of primer podcasts on stimulating learning from lectures: How do students engage?
}

Citation for published version (APA):

Popova, A., Kirschner, P. A., \& Joiner, R. (2014). Effects of primer podcasts on stimulating learning from lectures: How do students engage? British Journal of Educational Technology, 45(2), 330-339.

https://doi.org/10.1111/bjet.12023

DOI:

10.1111/bjet.12023

Document status and date:

Published: 01/03/2014

Document Version:

Other version

Please check the document version of this publication:

- A submitted manuscript is the version of the article upon submission and before peer-review. There can be important differences between the submitted version and the official published version of record. People interested in the research are advised to contact the author for the final version of the publication, or visit the DOI to the publisher's website.

- The final author version and the galley proof are versions of the publication after peer review.

- The final published version features the final layout of the paper including the volume, issue and page numbers.

Link to publication

\section{General rights}

Copyright and moral rights for the publications made accessible in the public portal are retained by the authors and/or other copyright owners and it is a condition of accessing publications that users recognise and abide by the legal requirements associated with these rights.

- Users may download and print one copy of any publication from the public portal for the purpose of private study or research.

- You may not further distribute the material or use it for any profit-making activity or commercial gain

- You may freely distribute the URL identifying the publication in the public portal.

If the publication is distributed under the terms of Article 25fa of the Dutch Copyright Act, indicated by the "Taverne" license above, please follow below link for the End User Agreement:

https://www.ou.nl/taverne-agreement

Take down policy

If you believe that this document breaches copyright please contact us at:

pure-support@ou.nl

providing details and we will investigate your claim.

Downloaded from https://research.ou.nl/ on date: 26 Apr. 2023 


\title{
Effects of primer podcasts on stimulating learning from lectures: How do students engage?
}

\section{Anguelina Popova, Paul A. Kirschner and Richard Joiner}

Anguelina Popova is a PhD candidate at the Open Universiteit Nederland. Paul A. Kirschner is Professor of Educational Psychology at the Centre for Learning Sciences and Technologies (CELSTEC) at the Open Universiteit Nederland and Scientific Director of the Netherlands Laboratory for Lifelong Learning. Richard Joiner is Senior Lecturer and Director of Studies for the Psychology Undergraduate programme in the Department of Psychology at the University of Bath, UK. Address for correspondence: Miss Anguelina Popova, CELSTEC, Open University of the Netherlands, Valkenburgerweg 177, Heerlen 6419 AT, The Netherlands. Email: angie.popova@gmail.com

\begin{abstract}
A number of factors can influence learning from lectures such as students' prior knowledge, their motivation, the instructional design, the lecturer and so forth. Instructional aid techniques such as preparing class notes, giving quizzes (either planned or spot quizzes) and the like can be used to maximise learning. This study uses two welldocumented tools for learning from text-advance organisers and higher order questions - adapted for use with podcasts. Student evaluations of their experience of being primed for lectures with podcasts are described. The findings show that audio advance organisers and questions experienced by students have a positive influence on learning, because they help students bridge the conceptual distance between new and prior knowledge, better understand the topics in the lectures and stimulate thinking more deeply about the lecture's content and the possible applications of the subject of the lecture.
\end{abstract}

\section{Introduction}

Well into the 21st century, lectures are still the dominant form of teaching in most institutions of higher learning. The exact benefit from a lecture is hard to predict. Some students prepare for them, whereas others expect to "learn it all" from the instructor during the lecture. Some students already have knowledge of the lecture topic, whereas others lack background knowledge and profit poorly from the new information. Also, instructors use lectures for different reasons. Some use them to rehash what was in the required readings, whereas others use them to broaden and deepen the readings. All of this means that lectures are seldom as effective as they could be.

The constructivist view of learning emphasises the role of active cognitive processing in learners. A number of techniques can be used to enhance this learning from lectures. Mayer $(2001,2005)$ identifies three cognitive processes that enhance meaningful learning, namely selecting (ie, paying attention to incoming information), organising (ie, building a coherent cognitive representation) and integrating (ie, connecting new knowledge with prior knowledge). Ohlsson (1995) contends that for optimal learning, a learning design should be created around certain learning activities that he calls epistemic tasks. These are tasks that are meant to stimulate the learner to describe, explain, predict, argue, critique, explicate and/or define. Learning is expected to be maximised as a result of organising knowledge and engaging students in these learning activities.

In the research described in this article, a cohort of undergraduate psychology students were exposed to pre-lecture (ie, primer) audio podcasts, throughout one semester. The purpose 